\title{
US politics: campaigns as usual
}

Neither the Republican nor Democratic party has produced a 'platform' spelling out a policy agenda for science and technology in any meaningful detail.

THE end of August brings with it the blessed end to the quadrennial summer of political conventions and writing of party 'platforms' as the Republican and Democratic candidates for the White House try to define themselves and distinguish themselves from their rivals. The Democratic platform, a clear statement of the goals of candidate Bill Clinton of Arkansas, gets right down to business with talk about investment in science and technology, education and the deficit. The Republican treatise, following President George Bush's lead, casts the party as the bastion of "family values". "As the family goes, so goes the nation."

It is well known that political platforms are not gospel, that they deal as much in rhetoric as in fact and detail. Nevertheless, they provide clues to the parties that set the tone for the campaign and, this year, reveal some striking changes in thinking, especially among the Democrats.

Taking a cue from former candidate Paul Tsongas of Massachusetts, who entered the campaign telling the Democrats that you cannot redistribute wealth that has not been created, the final version of the Democratic platform "rejects" the "big government theory that says we can hamstring business and tax and spend out way to prosperity". Sounding very Republican, the Democrats attest to a belief in "free enterprise and the power of market forces," aided by a "national economic strategy". Whether that means that Clinton really favours a formal economic or industrial policy remains to be seen.

But some points are spelled out. Clinton wants Congress to agree to reinvest defence savings in research and education (assuming that the so-called 'peace dividend' is real), and proposes an investment tax credit and a reduction in capital gains taxes (sounds like Bush) for "patient investors in emerging technologies and new business". But, in keeping with the Democrats' image as the party of the common man, Clinton has also proposed an unspecified tax increase for the wealthy, defined as an income of more than $\$ 200,000$ a year. The Democrats also think innovation and the US's competitive position vis-à-vis Japan and Germany deserve prominent mention. The party's second plank calls for a permanent research and development tax credit, and a doubling of basic research budgets for unidentified "key technologies".

By contrast, the Republican platform devotes its first several pages to the family, calling on good Republicans to "oppose and resist" Democratic party efforts to redefine the traditional family. That is to say, the Republicans reject the idea that homosexuals can form a family, and that they deserve special protection under civil rights laws. The Republicans officially deplore abortion and fetal tissue transplantation research, and propose reestablishing the "maternity homes" where unwed mothers used to go before the birth of a baby who was usually given up for adoption. The Republican platform rejects the distribution of condoms and clean needles as part of a programme to reduce the spread of AIDS, instead stressing abstinence and marital fidelity.

Although the emphasis and positioning in the platform is different, the Republicans express a belief in the connection between science and technology and increased economic productivity, with a list that covers the waterfront. Telecommunications, high-performance computers, high-speed data networks, digitization, advanced software, energy, agriculture, oceanography and geological research are among dozens of items that get a nod, though how increased research would be paid for is not mentioned.

Indeed, in his acceptance speech, Bush called for an economy-stimulating across-the-board tax cut (presumably income tax) coupled with reductions in federal spending in all areas except Social Security. However, he refused to give a single specific example of what he has in mind.

Taken together, the platform generalities and the candidates' rhetoric tell us little that is really substantive. Both Bush and Clinton want to end the economic downturn in the United States. Each wants strong families, though neither fully knows how to create them. (Here, it might be said, Clinton's idea of creating a government-funded work programme to create jobs rebuilding roads, bridges, and parks - reminiscent of Franklin D. Roosevelt - does offer one specific approach to employing youth.) After two months of talk from each side, instead of coherent, fully formed policy proposals, the United States is facing a fall campaign with an emphasis on name-calling and casting blame - Bush on the Democratic Congress that has been in power for the past 12 years, Clinton on the Reagan and Bush White House.

Meanwhile, serious challenges abound. For instance, the value of the dollar reached a new low against the German mark last week (the lowest since the Second World War) in response to US interest rates that the Federal Reserve Bank has pushed as low as 3 per cent to stimulate the economy while European nations, particularly Germany, are fighting inflation with interest rates as high as nine per cent.

Is it too much to hope for a presidential campaign focused on the national and international issues that are of substance? It would seem so. 